*ak RMIS View/Frint Document Cover Sheet tow

This document was retrieved from the Documentation and Records Manaqement (DRM) ISEARCH System. It is intended for Information only and may not be the most recent or updated version. Contact a Document Service Center (see Hanford Info for locations) if you need additional retrieval information.

Accession \#: D196080750

Document \#: SD-SNF-CSER-003

Title/Desc:

K BASINS CONSOLIDATED FUEL STORAGE \& HANDLING CRITICALITY SAFETY EVALUATION

Pages: 34 


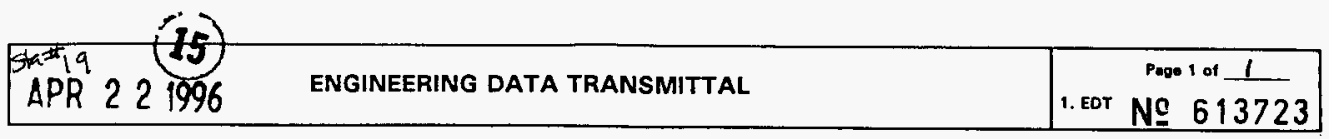

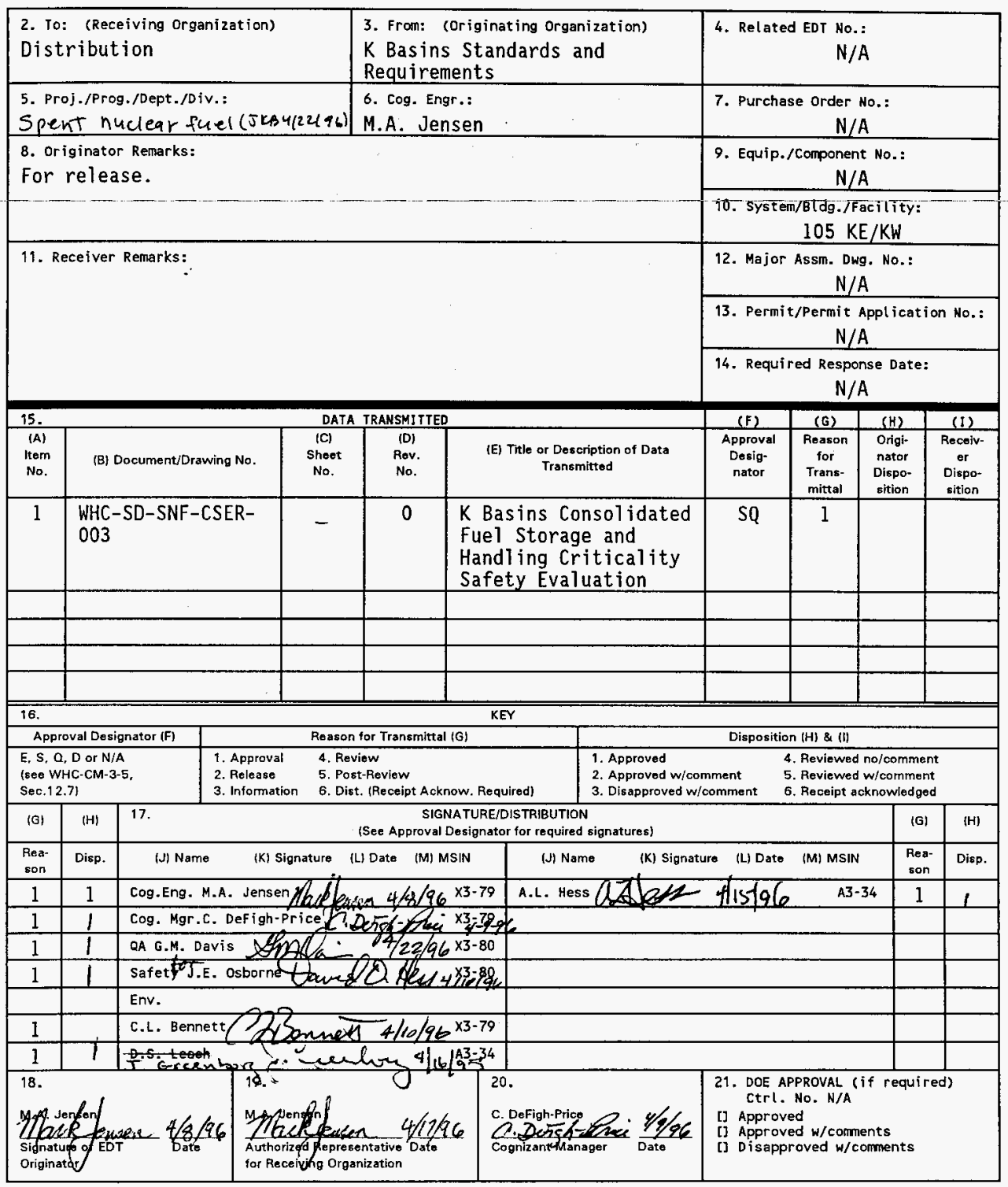

BD-7400-172-2(04/94) GEF097 


\title{
K Basins Consolidated Fuel Storage and Handling Criticality Safety Evaluation
}

\author{
M. A. Jensen
}

Westinghouse Hanford Co., Richland, WA 99352

U.S. Department of Energy Contract DE-AC05-87RL10930

EDT/ECN: 613723

Org Code: $2 A 340$

UC: 940

B\&R Code: EW3135040

Charge Code: LD008

Total Pages: 31

Key Words: Criticality, Criticality Safety Evaluation Report, K Basins, $N$ Reactor, Single Pass Reactor

Abstract: The bases for safe storage of irradiated $N$ Reactor and Single Pass Reactor (SPR) fuel in the Hanford $K$ Basins, as derived from existing criticality safety evaluation reports, have been consolidated in one supporting document.

TRADEMARK DISCLAIMER. Reference herein to any specific commercial product, process, or service by trade name, trademark, manufacturer, or otherwise, does not necessarily constitute or imply its endorsement, recommendation, or favoring by the United states Government or any agency thereof or its contractors or subcontractors.

Printed in the United States of America. To obtain copies of this document, contact: WHC/BCS Document Control Services, P.O. Box 1970, Mailstop H6-08, Richland WA 99352, Phone (509) 372-2420; Fax (509) 376-4989.

quis \&aden

Release Approval
4122196

Date

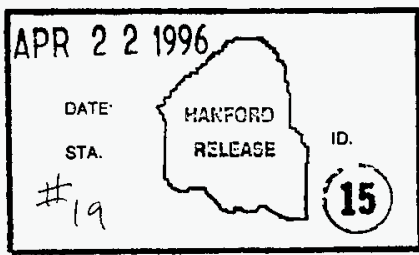

Release Stamp

\section{Approved for Public Release}


WHC-SD-SNF-CSER-003 ReV 0

K BASINS CONSOLIDATED FUEL STORAGE AND HANDLING CRITICALITY SAFETY EVALUATION

M. A. Jensen 
Table of Contents

1.0 INTRODUCTION . . . . . . . . . . . . . . . . . . . . . 1 1.1 Note on English vs. Metric Units . . . . . . . . . 1

2.0 DESCRIPTION OF SYSTEM AND FACILITY . . . . . . . . . . . 2

3.0 REQUIREMENTS DOCUMENTATION . . . . . . . . . . . . . . . . 4

4.0 FUEL STORAGE LIMITS . . . . . . . . . . . . . . . . . . . . 4

4.1 Floor Rack Storage . . . . . . . . . . . . . . . . 4

4.2 Suspended Fuel Storage . . . . . . . . . . . . . . 4

4.2 .1 Storage in the West Bays . . . . . . . . . . 5

4.4 SPR Fuel of Unidentified Enrichment . . . . . . . . 6

4.5 SPR Fuel of Identified Enrichments . . . . . . . . 6

5.0 FUEL HANDLING AND MOVEMENT . . . . . . . . . . . . . . . . 7

5.1 Canisters on Hoists per Storage Bay . . . . . . . . 7

5.2 Spilled Fuel . . . . . . . . . . . . . . . . . . . 7

5.3 Amount of Fuel Per Container . . . . . . . . . . . 8

5.4 Canister Decapping at $\mathrm{k}$ West . . . . . . . . . . . 8

5.5 Fuel Shipments . . . . . . . . . . . . . . . . . . 9

5.5.1 N Reactor Fuel Shipments. . . . . . . . . . 9

5.5.2 SPR Fuel Shipments... . . . . . . . 10

6.0 REFERENCES . . . . . . . . . . . . . . . . . . . . . . . 11

Appendix A . . . . . . . . . . . . . . . . . . . . . . . . . . . . A1

English Factor Weights for $\mathrm{N}$ Reactor Fuel in $\mathrm{K}$ Basins - A2

English Dimensions for $N$ Reactor Fuel . . . . . . . . . A4

English Dimensions for K Basins SPR Fuel . . . . . . . . A4

Metric Factor Weights for $\mathrm{N}$ Reactor Fuel in $\mathrm{K}$ Basins. . A5

Metric Dimensions For N Reactor Fuel . . . . . . . . . . A7

Metric Dimensions for K Basins SPR Fuel . . . . . . . . A7

References... . . . . . . . . . . . . . . . . . A8

Notes . . . . . . . . . . . . . . . . . . . . . A9

Appendix B . . . . . . . . . . . . . . . . . . . . . . . . . . B1

Figure 1 K Basin Plan . . . . . . . . . . . . . . . . . B2

Figure 2 K Basin Fuel Storage Canisters... . . . . . . B3

Figure 3 k Basin Fuel Storage Racks . . . . . . . . . . B4

Figure 4 N Reactor Fuel Assembly . . . . . . . . . . . B5

Appendix C . . . . . . . . . . . . . . . . . . . . . . . . . . . . . .

Technical Peer Review . . . . . . . . . . . . . . . C2 
WHC-SD-SNF-CSER-003 Rev 0

\section{K BASINS CONSOLIDATED FUEL STORAGE AND HANDLING \\ CRITICALITY SAFETY EVALUATION}

\subsection{INTRODUCTION}

The $100 \mathrm{~K}$ fuel storage basins, designated $\mathrm{K}$ East and $\mathrm{K}$ West, were constructed in the 1950s for initial storage and cooling of irradiated fuel from the $K$ Reactors prior to shipment for plutonium extraction. The reactors and basins were shut down and deactivated in the early 1970s. Subsequently the basins, first $K$ East, and later $\mathrm{K}$ West, were reactivated to store $\mathrm{N}$ Reactor fuel.

Current $\mathrm{K}$ Basin fuel handling and storage criticality safety limits are derived from a large number of criticality safety evaluations dating from 1969. In many cases, these documents were written to cover an aspect of operations (for example, N Reactor fuel storage) that are no longer applicable; however portions of the analyses are being used to support $\mathrm{K}$ Basin limits. In some cases the bases for storage or handling are not clearly defined or were derived from erroneous assumptions or misinterpretations of earlier analyses.

This evaluation consolidates the existing bases for fuel handling and storage in the $\mathrm{K}$ Basins and provides bases for currently-used limits in those cases where the derivation of the limits are unclear. It does not perform new analyses nor does it incorporate evaluations for fuel encapsulation, sludge cleanup, or plutonium accumulations in filtration components. Recent, detailed analyses using modern computer codes have been performed for these operations and conditions. Additionally, it does not provide a basis for eliminating the older CSERs. This document provides a summary of existing analyses and provides a means for applying them to facility operating limits, and provides bases for existing limits that do not have clearly-defined bases.

\section{I.1 Note on English vs. Metric Units}

$N$ Reactor and SPR fuel were manufactured to English dimensions. The reported fuel lengths, e.g. 26 inches, are nominal values. All previous documentation relating to the fuel, as well as accountability records, use English dimensions. Appendix A provides both metric and English values for the lengths, diameters, and factor weights.

Most of the facility limits for fuel storage and handling are based on English units. Although the metric equivalents are stated in the text of this document, with the English values given parenthetically, it must be understood that the English 
WHC-SD-SNF-CSER-003 Rev 0

values, in most cases, are the actual limits, as derived from the applicable criticality safety evaluations and applied in Process Standards.

\subsection{Note on Existing Criticality Safety Evaluations}

Several criticality safety evaluations have been prepared in the past in support of $\mathrm{N}$ Reactor and $\mathrm{K}$ Basins fuel storage. These evaluations assume that stored fuel is unirradiated and therefore contains the original amount of ${ }^{235} \mathrm{U}$; no credit is taken for burnup or the presence of fission product poisons. Although the effect of this assumption is that ${ }^{239} \mathrm{Pu}$ is not considered, the typical irradiation history of the fuel ensures that irradiated fuel is less reactive than unirradiated fuel. This was demonstrated by a subcritical experiment using both unirradiated and irradiated fuel (Toffer 1976). Calculated critical masses for both irradiated "safe exposure" and irradiated "average discharge exposure" were considerably higher than calculated critical masses for unexposed fuel. Thus the evaluations summarized in this document provide substantial conservatism.

\subsection{DESCRIPTION OF SYSTEM AND FACILITY}

$K$ Basins consists of two large water-filled basins ( $K$ East and $K$ West) used to store irradiated fuel discharged from the $\mathrm{N}$ Reactor (see Figure 1 in Appendix B). Small amounts of unirradiated $N$ Reactor fuel are also stored in the basins. Small amounts of fuel from the Hanford Single-Pass Reactors (SPR) are also stored at each basin. The storage basins are subdivided into three storage bays, designated East, Center, and West. The bays are separated by concrete walls approximately 0.6 meters (two feet) thick.

N Reactor fuel consists of an annular outer tube and an annular inner tube of zirconium-clad uranium. A fuel assembly consists of an inner tube inserted into the outer tube. Outer tubes or inner tubes by themselves are called "fuel elements" or "outers" and "inners" respectively. The fuel elements come in several different lengths (from 30.5 to $66 \mathrm{~cm}$ or 12 to 26 inches) and in three different predominant enrichments (natural uranium, or 0.71 wt $\%{ }^{235} \mathrm{U}, 0.95$ wt $\%{ }^{235} \mathrm{U}$, and 1.25 wt $\left.\%{ }^{235} \mathrm{U}\right)$. For purposes of criticality safety and convenience in handling, 0.71 wt\% ${ }^{235} \mathrm{U}$ fuel is treated as if it were 0.95 wt: fuel. Enrichments between 0.95 and 1.25 wt\% also exist; these are handled as 1.25 wt\% enriched fuel. 1.25 wt\% assemblies (also known as MK IA assemblies or "spike" assemblies) have outer elements with a 1.25 wt: enrichment and inner elements with a 0.95 wt\% enrichment. 1.25 wt: fuel is stored only at the $K$ West basin. The majority of 0.71 wt\% and 0.95 wt\% fuel assemblies are designated as "MK IV" 
assemblies, however some earlier fuel assembly designs (0.71 wt\% MK IB assemblies and 0.95 wt\% MK IC assemblies) exist in the basins. A complete list of fuel lengths, types, enrichments, factor weights (weight of uranium in the fuel element or assembly excluding weight of cladding, support clips, etc.), and diameters is given in Appendix $A$ in both English and metric units.

Both basins contain "scrap" fuel, which is defined as small pieces of fuel that cannot be packaged with the associated fuel assemblies or elements.

SPR fuel is in the form of aluminum-clad solid slugs or single annular aluminum-clad tubes. K East enrichments are 0.71 wt: and 0.95 wt\%. K West contains depleted uranium SPR with enrichments of 0.141 wt: and 0.22 wt: and "undetermined" enrichment (although no more than 1.25 wt\% equivalent). The $\mathrm{K}$ west depleted SPR fuel is handled and stored as $0.95 \mathrm{wt} \%$ SPR and the undetermined enrichment SPR is handled and stored in a manner similar to that of 1.25 wt\% scrap fuel. SPR fuel ranges from 12.7 to $20.3 \mathrm{~cm}$ (five to eight inches) in length and the weight varies from 2.1 to $3.86 \mathrm{~kg}(4.60$ to 8.52 lbs). Appendix A contains a listing of SPR fuel types currently stored in the basins.

Both basins have water filtration systems consisting of cartridge filters, a sand filter, and ion exchange modules. These components filter uranium, plutonium, and fission products from the basin water and may contain a measurable inventory of plutonium/uranium. The source of the uranium and plutonium is suspended and dissolved material from corroded fuel assemblies. Fuel at $\mathrm{K}$ East is stored in open canisters which allows uranium and plutonium corrosion products to become suspended in the basin water. Fuel at $\mathrm{K}$ West is stored in closed canisters and very little uranium or plutonium has leached into the basin water. Historical center-of-basin water samples show that the basin water plutonium concentration at $\mathrm{K}$ East is approximately three orders of magnitude higher than at $\mathrm{K}$ west.

Fuel is stored in double-barrelled canisters which hold a maximum of seven assemblies per barrel. Canisters are placed in racks $\left(53 \mathrm{~cm} \times 27 \mathrm{~cm}\right.$ or $\left.21^{\prime \prime} \times 10.6 "\right)$ installed on the basin floor. Each rack can contain a maximum of one canister. stacking is not allowed nor is it physically possible with the existing rack design. Both basins have equipment in place to suspend canisters over the racks in a "one over three" arrangement but this storage arrangement is not in use and is prohibited by the facility Process Standards. A small amount of SPR fuel stored in $\mathrm{K}$ East is in baskets rather than canisters. This fuel is stored in the Technical View pit which is adjacent to the main storage basin. 
WHC-SD-SNF-CSER-003 ReV 0

\subsection{REQUIREMENTS DOCUMENTATION}

This evaluation is being prepared in accordance with the requirements for criticality safety evaluations in WHC-CM-4-29, Nuclear Criticality Safety Manual, chapter 4.0.

\subsection{FUEL STORAGE LIMITS}

Fuel storage in floor racks, suspended storage, west bay storage, and storage of 1.25 wt: scrap and single pass reactor fuel are discussed in this section.

\subsection{Floor Rack Storage}

A series of criticality evaluations (Toffer 1975, Toffer 1976 , Toffer et al 1980), culminating in an evaluation of full-density storage with suspended fuel storage (Toffex and Eaves, 1981) were performed to determine the safety of fuel storage in the floor racks. It was determined that full-density floor storage (every storage location filled), with full-density water reflection, has $a k_{\text {eff }}$ of 0.755 for MK IA fuel. For optimum moderation, the $k_{\text {eff }}$ increased to 0.939. Optimum moderation requires a partial drain of the basin water, an unlikely condition. For a dry basin (water in canisters only) the $k_{\text {eff }}$ is 0.876 . As MK IV fuel is less reactive, this analysis is bounding for all types of $\mathrm{N}$ Reactor fuel.

The initial calculations were verified by performance of subcritical experiments with unirradiated and irradiated $N$ Reactor fuel (Toffer 1976). Finally, subcritical experiments for storage configurations for MK IA fuel (which are bounding for less-reactive MK IV fuel) were performed to verify the safety of fuel storage in $\mathrm{K}$ West (Roblyer 1982).

\subsection{Suspended Fuel Storage}

Suspended fuel storage in a "one over three" arrangement was analyzed in Toffer and Eaves (1981). The worst-case single contingency accident involved spilling all suspended fuel alongside floor-stored canisters at optimum lattice pitch with full-density basin water. The $k_{\text {eff }}$ in this case was 0.936 , which is less than the safety factor of 0.98 . A "one over two" array had $a k_{\text {eff }}$ of 0.992 for the same accident; thus this method of suspended storage is not allowed. The analysis assumes both floor-stored and suspended fuel is MK IA in aluminum canisters. Substituting either MK IV fuel in place of MK IA fuel or stainless steel canisters in place of aluminum canisters reduced $\mathrm{k}_{\text {eff }}$ significantly. Suspension of 1.25 wt: scrap canisters or suspension of fuel of any enrichment over 1.25 wt: scrap 
WHC-SD-SNF-CSER-003 Rev 0

canisters is not allowed (Tollefson 1983).

\subsubsection{Storage in the West Bays}

The $\mathrm{K}$ Basins Operational Safety Requirements (Jensen 1996) prohibits storage of 1.25 wt: enriched fuel in the west bay of $k$ West (1.25 wt: fuel is not allowed anywhere in $\mathrm{K}$ East). Suspended fuel of any enrichment is not allowed in the west bay of $\mathrm{K}$ West or $\mathrm{K}$ East. A runaway train transporting a full load of fuel could crash into the basin and take any suspended fuel with it into the fuel stored on the basin floor. This accident is similar to a suspended fuel failure in the "one over two" mode, which was shown to exceed a $k_{\text {eff }}$ of 0.98 (Toffer and Eaves, 1981). Thus neither suspended fuel nor 1.25 wt: fuel are allowed in the west bay of either basin.

\subsection{1 .25 wt\% Scrap Canisters}

1.25 wt: scrap is more reactive than 1.25 wt\% assemblies because the scrap fuel more closely approaches an optimum geometry. In order to maintain equivalent reactivity between a scrap canister and an assembly canister, it is necessary to restrict the mass of scrap to the same percentage of the hemispherical critical mass as that of a canister of assemblies.

The hemispherical critical mass for 1.25 wt: assemblies is 3211 $\mathrm{kg}(7080 \mathrm{lbs})$ and is $1172 \mathrm{~kg}(2584 \mathrm{lbs})$ for scrap (Schwinkendorf 1994). A canister loaded with fourteen "M" length (53 cm or 21 inch) 1.25 wt\% assemblies has a mass of $233 \mathrm{~kg}$ (514 1bs) which is $7.3 \%$ of $3211 \mathrm{~kg}$. Limiting the scrap canisters to no more than $85.0 \mathrm{~kg}$ (187 lbs) will maintain the scrap canisters at approximately the same reactivity as the assembly canisters. Process Standards limits 1.25 wt: scrap canisters to 180 lbs (approximately $82 \mathrm{~kg}$ ).

Because of the potentially higher reactivity of the scrap fuel, Tollefson (1983) required a nominal 0.3 meters (one foot or one empty storage rack) isolation for each two scrap canisters from all other fuel. A concrete wall, such as those dividing the basin into the three bays, is considered to provide equivalent neutronic isolation. If 1.25 wt: scrap fuel is spilled during transport in the basin, no other fuel movements within 3.0 meters (10 feet) are allowed until the fuel is recovered. Criticality calculations indicate a reactivity increase of up to $150 \mathrm{mk}$ for such a spill. It should be noted that Tollefson appears to assume the canisters contain a mass of scrap roughly equivalent to 141.25 wt: assemblies (about $233 \mathrm{~kg}$ or 514 lbs) because no mass limits for the scrap canisters are given in the CSER. The spacing restrictions will not be changed by this document. 
WHC-SD-SNF-CSER-003 Rev 0

\subsection{SPR Fuel of Unidentified Enrichment}

$K$ West basin contains a small amount (47 pieces) of unidentified SPR fuel. This fuel was retrieved from the cleanout of the $C$ Reactor basin and is most likely 0.95 or 0.71 wt $\%$ enriched. However, the fuel has not been positively identified. C Reactor occasionally used a fuel model ("J" metal) with a 93 wt: ${ }^{235} \mathrm{U}-$ aluminate matrix fuel design that had an effective enrichment of $1.25 \mathrm{wt} \%{ }^{235} \mathrm{U}$; $i . e .$, the fuel has the same reactivity as 1.25 wt SPR fuel. The cylindrical critical mass of this fuel is approximately $54.4 \mathrm{~kg}(120 \mathrm{lbs})$ or 100 pieces (Kupinski and Toffer, 1970). The spherical and hemispherical critical masses were not calculated for this fuel. A conservative approach is to limit the number of pieces per canister to $30 \%$ of the critical mass; this equals 30 pieces. Thus a canister may contain no more than 30 pieces of unidentified SPR fuel.

In order to isolate this potentially more reactive fuel from other fuel, each canister must be stored with a nominal 0.3 meter (one foot) (one empty storage rack or one concrete wal1) separation from all other fuel, including other canisters of unidentified SPR. This conservative approach prevents inadvertent intermixing of different fuel types which would require further analysis to determine the impact on basin or subarray reactivity.

If this fuel is positively identified (for example, by actual piece weight; $J$ metal weighs $0.54 \mathrm{~kg} v s$. between 2.1 and $3.6 \mathrm{~kg}$ for typical SPR fuel) then the SPR requirements of the following section apply.

\subsection{SPR Fuel of Identified Enrichments}

A total of 138 pieces of SPR fuel are stored in $\mathrm{K}$ East in three canisters and two baskets. 786 pieces are stored in $K$ West in 20 canisters. Enrichments are 0.71 wt\% (natural uranium) and 0.95 wt $\%$ at $K$ East and 0.141 wt\% and 0.0673 wt\% (depleted uranium) at $\mathrm{K}$ West. All of the fuel is handled as if it were $0.95 \mathrm{wt} \%$. The spherical critical mass for $0.95 \mathrm{wt} \%$ SPR fuel is $4944 \mathrm{~kg}$ or 10,900 lbs (Chitwood 1969). Although a hemispherical spill is more realistic than a spherical spill, the hemispherical critical mass is not available. The intent is to limit the amount of SPR in a container such that a spill will have a reactivity effect similar to that of a spill of $N$ Reactor fuel. A canister of "E" length (66 cm or 26 inches) $0.95 \mathrm{wt} \%$ assemblies weighs $327.68 \mathrm{~kg}$ (722.40 lbs). The spherical critical mass for the assemblies is $7795 \mathrm{~kg}$ or 17,184 lbs (Schwinkendorf 1994); one canister contains $4.2 \%$ of a critical mass. A convenient percentage of the SPR critical mass that approximates the reactivity of a canister 
of $\mathrm{N}$ Reactor fuel is five percent. Therefore an SPR container may hold no more than $247 \mathrm{~kg}$ (545 lbs).

Due to the potentially higher reactivity of SPR fuel and the lack of knowledge regarding mixtures with $N$ Reactor fuel, SPR fuel requires a 0.3 meter (one foot) or empty rack or concrete wall isolation from all other fuel.

The SPR container in $\mathrm{K}$ East with the most fuel contains approximately $167 \mathrm{~kg}$ (368 lbs) or $3.4 \%$ of a critical mass. In $\mathrm{K}$ West, the canister with the most fuel contains $179 \mathrm{~kg}$ (395 los) or $3.6 \%$ of a critical mass.

\subsection{FUEL HANDLING AND MOVEMENT}

This section discusses moving canisters on hoists in the main basin, handling in the event of fuel spills, amount of fuel allowed per container, canister decapping at $\mathrm{K}$ West, and fuel shipments to and from the basins.

\subsection{Canisters on Hoists per storage Bay}

Process Standards limits the number of canisters out of storage and on hoists to three per bay, with the further limitation that only one scrap canister may be out of storage anywhere in the basin. The canisters are required to be separated by at least 0.9 meters (three feet) while in transit. Toffer (1975) determined that a spill of one canister into a six canister subarray has a minimal reactivity perturbation. With the canister rack dimensions of $53 \mathrm{~cm} \times 27 \mathrm{~cm}$ (21" x 10.6") a six canister subarray is $160 \mathrm{~cm} \mathrm{x} 81 \mathrm{~cm}\left(63^{\prime \prime} \times 31.8^{\prime \prime}\right.$ or $5.25^{\prime} \mathrm{x}$ $\left.2.7^{\prime}\right)$. A 0.9 meter separation for the canisters assures that a multiple spill from the hoists will not drop more than one canister into the six canister subarray. This accident is also simulated by a drop of suspended fuel in the one-over-three arrangement; canisters suspended fuel in this arrangement would be approximately 0.9 meters apart.

\subsection{Spilled Fuel}

As previously mentioned (section 4.3), a spill of 1.25 wt: scrap requires a suspension of all fuel movement within 3.0 meters of the spill until the scrap fuel is recovered. Process standards conservatively applies this restriction to spills of all types of fuel. 
WHC-SD-SNF-CSER-003 Rev 0

\subsection{Amount of Fuel Per Container}

Fuel canisters are limited to 14 fuel assemblies or the equivalent weight of disassembled fuel. Up to $327.7 \mathrm{~kg}(722 \mathrm{lbs})$ of $0.95 \mathrm{wt} \%$ scrap, which is equivalent to 14 of the longest 0.95 wt: assemblies, is allowed in one canister. This restriction does not include SPR fuel which is covered by different limits (see sections 4.3 .2 and 4.3 .3 ). This restriction assures that, in the event of a canister or multiple canister spill, no more fuel than the equivalent mass of 14 assemblies will be involved per canister. It also assures that a canister won't contain more fuel than is assumed for basin floor rack storage reactivity calculations (Toffer 1976).

\subsection{Canister Decapping at $\mathrm{K}$ West}

The $\mathrm{K}$ West decapping station is in the south loadout pit transfer channel. A maximum of four canisters are allowed in the transfer channel; a maximum of one may be out of the provided storage racks or the canister receptacle where the actual decapping takes place (Tollefson 1983). Four canisters of 1.25 wt\% fuel contain 29\% of the hemispherical critical mass (Schwinkendorf 1994). It would take the fuel from more than 13 canisters, spilled into an optimally-moderated and spaced hemisphere, to reach the hemispherical critical mass of $3211 \mathrm{~kg}$ (7080 1bs), and more than ten canisters to reach the hemispherical $k_{\text {eff }}=0.98$ mass of 2464 $\mathrm{kg}$ (5433 lbs).

In addition to the four canisters allowed in the transfer channel, up to four additional canisters may be in the loadout pit itself. If the fuel from both locations were to spill into a single optimally-moderated and spaced hemisphere (again assuming 1.25 wt $\%$ fuel), there would be a total mass of $1866 \mathrm{~kg}$ (4113 $1 \mathrm{bs}$ ) or about $58 \%$ of the critical mass and $76 \%$ of the $k_{\text {eff }}=0.98$ mass. More than two additional canisters would be required before the $k_{\text {eff }}=0.98$ mass would be reached. Thus a single contingency (one additional canister in one of the two locations) will not exceed the basin control limit.

Once decapping operations have taken place in the $\mathrm{K}$ West decapping station, a sludge height limit of no more than $14.7 \mathrm{~cm}$ (5.8 inches) applies (Tollefson 1983). Safe slab heights are generally $45 \%$ of the minimum critical slab, which would be 32.7 $\mathrm{cm}$ (12.9 inches) in this case. K East does not have a similar sludge height limit due to the restriction against 1.25 wt: enriched uranium. Homogeneous hydrogenous uranium solutions with an effective enrichment of less than 1.0 wt: ${ }^{235} \mathrm{U}$ cannot be made critical (Neely and Handler, 1961). 
Sludge heights are measured in the $k$ west transfer channel by means of a four-legged pylon shaped like a jack or caltrop. Three legs of the pylon maintain contact with the transfer channel floor; the fourth extends straight up. Each leg is marked with the maximum sludge height so that no matter how the pylon is oriented on the floor the indicating leg marking is visible provided the sludge depth is within limits.

\subsection{Fuel Shipments}

Both $K$ East and $K$ West basins are designed to allow for shipments of fuel either to or from other Hanford locations. For shipments out of the basin, fuel is transported to the south loadout pit via the basin hoist and trolley system. Casks which can contain up to three canisters are loaded and removed from the pit by the building crane and placed into a railroad well car. The well car can contain three casks; thus a well car can transport up to nine canisters of fuel. Fuel shipments to the basin are accomplished in a similar manner--the well car casks are lowered one at a time into the loadout pit and the canisters are removed and stored in the basin. Fuel shipped to or from the basin in trucks rather than the standard well cars are administratively limited to contain no more fuel than would be allowed in a well car.

\subsubsection{N Reactor Fuel Shipments}

A well car containing nine canisters of 1.25 wt: fuel (M length; see Appendix A), holds $2099 \mathrm{~kg}$ (4627 lbs). This represents 65\% of the hemispherical critical mass of $3211 \mathrm{~kg}(7080 \mathrm{lbs})$

(Schwinkendorf 1994). Westinghouse Hanford Company criticality control criteria state that the maximum acceptable $k_{\text {eff }}$, after any foreseeable contingency is less than or equal to 0.98 (WHC 1994). This CSER limits the number of loaded well cars in the facility to one and a well car cannot contain more than nine canisters; thus a double-batching accident following a well car spill is not credible.

If the fuel from one well car should spill in such a way as to cause the inners and outers to separate into distinct hemispheres, the pile of outers, which are more reactive, would have a mass of $1404 \mathrm{~kg}$ (3095 lbs) which is less than the $k_{\text {eff }}=$ 0.98 mass of $1469 \mathrm{~kg}(3239 \mathrm{lbs})$. Thus after two contingencies (the rail car spill and the disassembly of fuel into two piles, one representing the most reactive configuration), the subcritical criteria is satisfied.

If the well car contains nine canisters of scrap, the total mass would be $763 \mathrm{~kg}$ (1683 lbs). This represents $81 \%$ of the hemispherical critical mass of $941 \mathrm{~kg}$ (2075 lbs) for 1.25 wt\% 
WHC-SD-SNF-CSER-003 ReV 0

scrap; thus even with the more reactive scrap fuel a well car contains insufficient material to exceed a $k_{\text {eff }}$ of 0.98 .

Well cars containing 0.95 wt: fuel or scrap are bounded by the above analyses because the $0.95 \mathrm{wt} \%$ fuel and scrap is less reactive than 1.25 wt: fuel and scrap.

\subsubsection{SPR Fuel Shipments}

SPR fuel may be shipped in two ways. Canisters limited to $247 \mathrm{~kg}$ (545 lbs) may be shipped three per cask and nine per well car. The total mass in a well car is $2225 \mathrm{~kg}(4905 \mathrm{lbs})$ or $45 \%$ of the critical mass of $4944 \mathrm{~kg}(10,900 \mathrm{lbs})$. Alternatively, fuel may be received or shipped in a special SPR basket, traditionally used for fuel shipments during the operation of the single pass reactors. Each basket can hold approximately 240 pieces of fuel. At a maximum mass of $3.86 \mathrm{~kg}$ per piece ( 8.52 lbs), the basket could hold about $928 \mathrm{~kg}(2045 \mathrm{lbs})$ or about $19 \%$ of a critical mass. Baskets are larger than canisters and only one can fit into a cask. Thus the total well car loading is three SPR baskets or about $2783 \mathrm{~kg}(6135 \mathrm{lbs})$. This is about $56 \%$ of the critical mass; thus although a well car of SPR fuel in baskets contains more fuel than a well car containing canisters, the total mass is still bounded by the limits for 1.25 wt: fuel. There are only two canisters of "unidentified" SPR fuel with a total piece count of 47 . This fuel requires careful separation from all other fuel and thus may not be shipped in combination with any other fuel. One shipment containing both canisters would contain at most about $47 \%$ of the critical amount (approximately 100 pieces) and a spill will not cause a criticality. 
WHC-SD-SNF-CSER-003 Rev 0

\subsection{REFERENCES}

Chitwood, R.A., 1969, N Reactor Technical Basis for Ex-Reactor Criticality Safety Specifications and Process Standards, DUN-2894 Rev1, Douglas United Nuclear Corp., Richland, WA.

Kupinski, A.F. and Toffer, H., 1970, Use of the Hammer System for Evaluating Light-Water Moderated, Critical Assemblies, DUN-7286, Douglas United Nuclear Corp., Richland, WA.

Jensen, M.A., 1996, Operational Safety Requirements - 100-KE and 100-KW Fuel Storage Basins, WHC-SD-WM-OSR-006 Rev1, Westinghouse Hanford Co., Richland, WA.

Neely, V.I. and Handler, H.E., 1961, Measurement of Multiplication Constant for Slightly Enriched Homogeneous $\mathrm{UO}_{3}-$ Water Mixtures and Minimum Enrichment for Criticality, HW-70310, General Electric Corp., Richland, WA.

Roblyer, S.P., 1982, PT-N-506 Subcritical Measurements in the Hanford KW Reactor Fuel Storage Basin, Final Report, UNI-1775D, UNC Nuclear Industries, Richland, WA.

Schwinkendorf, K.N., 1994, Criticality Safety Evaluation Report for 300 Area $N$ Reactor Fuel Fabrication and Storage Facility, WHC-SD-NR-CSER-010 Rev 0, Westinghouse Hanford Co., Richland, WA.

Toffer, H., 1975, Nuclear Criticality Safety Analysis and Technical Basis for the Storage of $N$ Reactor Irradiated Fuels in $K$ Reactor Basins, UNI-283, United Nuclear Industries, Richland, WA.

Toffer H., 1976, Nuclear Criticality Safety Analysis and Technical Basis for the storage of $N$ Reactor Irradiated Fuels in $K$ Reactor Basins - 1900 Ton Capacity, UNI-283 ADD1, United Nuclear Industries, Richland WA. 
Toffer, H., wittekind, W.D., and Meriwether, G.H., 1980, Nuclear Criticality Safety Analysis and Technical Basis for the storage of Encapsulated Fuel in. K Basin, UNI-1526, United Nuclear Industries, Richland, WA.

Toffer, H. and Eaves, J.H., 1981, Nuclear Criticality Safety Analysis and Technical Basis for Contingent Irradiated Fuel Storage in 105-KE/KW Basins, UNI-1779, United Nuclear Industries, Richland, WA.

Tollefson, D.A., 1983, Decapping/Recanning Operation Criticality Safety Analysis for $K E / K W$ Installation, UNI-2648, United Nuclear Industries, Richland, WA.

WHC, 1994, Nuclear Criticality Safety Manual, WHC-CM-4-29 section 2.0 Rev. 0 change 1, Westinghouse Hanford Co., Richland, WA.

Wittekind, W.D., 1992, K Basin Criticality Evaluation for Irradiated Fuel Canisters in Sludge, WHC-SD-NR-CSER-001 Revo, Westinghouse Hanford Co., Richland, WA. 
WHC-SD-SNF - CSER-003 ReV 0

Appendix A

Factor Weights and Dimensions for

N Reactor and Single Pass Reactor Fuel 


\begin{tabular}{|c|c|c|c|c|}
\hline \multicolumn{5}{|c|}{ English Factor Weights for N Reactor Fuel in K Basins (Doriss, 1970 and Locati, 1986) ${ }^{1}$} \\
\hline Description & Fuel Type & Fuel Code & Factor Weight, lbs. & Enrichment wt\% ${ }^{235} \mathrm{U}$ \\
\hline $26^{\prime \prime}$ spike outer & & A12E & 30.69 & 1.25 \\
\hline $26^{\prime \prime}$ spike inner & & N09E & 15.33 & 0.95 \\
\hline $26^{m}$ spike assembly & MK IA & A12NO9E & 46.02 & \\
\hline $21^{n}$ spike outer & & $\mathrm{A} 12 \mathrm{M}$ & 24.56 & 1.25 \\
\hline $21^{\prime \prime}$ spike inner & & N09M & 12.16 & 0.95 \\
\hline $21^{\prime \prime}$ spike assembly & MK IA & A12N09M & 36.72 & \\
\hline 19.5" spike outer & & $\mathrm{A} 12 \mathrm{~T}$ & 22.99 & 1.25 \\
\hline $19.5^{\prime \prime}$ spike inner & & N09T & 11.38 & 0.95 \\
\hline $19.5^{n}$ spike assembly & MK IA & A12NO9T & 34.37 & \\
\hline $15^{\prime \prime}$ spike outer & & $\mathrm{A} 12 \mathrm{~F}$ & 17.39 & 1.25 \\
\hline $15^{n}$ spike inner & & No9F & 8.60 & 0.95 \\
\hline $15^{\prime \prime}$ spike assembly & MK IA & A12FN09F & 25.99 & \\
\hline $26^{\prime \prime}$ standard outer & & $\mathrm{B} 09 \mathrm{E}$ & 35.10 & 0.95 \\
\hline $26^{\prime \prime}$ standard inner & & X09E & 16.50 & 0.95 \\
\hline $26^{\prime \prime}$ standard assembly & MK IV & B09X09E & 51.60 & \\
\hline $24.5^{\prime \prime}$ standard outer & & $\mathrm{B} 09 \mathrm{~S}$ & 32.98 & 0.95 \\
\hline $24.5^{\prime \prime}$ standard inner & & Xo9S & 15.52 & 0.95 \\
\hline $24.5^{\prime \prime}$ standard assembly & MK IV & B09X09S & 48.50 & \\
\hline $23 "$ standard outer & & $\mathrm{B} 09 \mathrm{~A}$ & 31.12 & 0.95 \\
\hline $23 "$ standard inner & & $\mathrm{X09A}$ & 14.64 & 0.95 \\
\hline $23^{\prime \prime}$ standard assembly & MK IV & B09X09A & 45.76 & \\
\hline $23^{n}$ standard outer & & $\mathrm{A} 09 \mathrm{~A}$ & 27.95 & 0.95 \\
\hline $23 "$ standard inner & & No9A & 13.96 & 0.95 \\
\hline $23^{n}$ standard assembly & MK IC & A09N09A & 41.91 & \\
\hline $22^{n}$ standard outer & & $\mathrm{B} 09 \mathrm{R}$ & 29.45 & 0.95 \\
\hline $22 "$ standard inner & & $\mathrm{X} 09 \mathrm{R}$ & 13.90 & 0.95 \\
\hline $22 "$ standard assembly & MK IV & B09X09R & 43.35 & \\
\hline $19^{\prime \prime}$ standard outer & & A09P & 22.18 & 0.95 \\
\hline $19^{n}$ standard inner & & N09P & 11.07 & 0.95 \\
\hline $19^{\prime \prime}$ standard assembly & MK IC & A09N09P & 33.25 & \\
\hline
\end{tabular}




\begin{tabular}{|c|c|c|c|c|}
\hline \multicolumn{5}{|c|}{ English Factor Weights for N Reactor Fuel in K Basins } \\
\hline Fuel Description & Fuel Type & Fuel Code & Factor weight, lbs. & Enrichment, wt\% ${ }^{23 s} \mathrm{U}$ \\
\hline $17^{n}$ standard outer & & $\mathrm{A} 09 \mathrm{C}$ & 20.29 & 0.95 \\
\hline $17^{\prime \prime}$ standard inner & & N09C & 10.13 & 0.95 \\
\hline $17^{\prime \prime}$ standard assembly & MK IC & A09N09C & 30.42 & \\
\hline $17^{\prime \prime}$ standare outer & & $\mathrm{B} 09 \mathrm{C}$ & 23.19 & 0.95 \\
\hline $17^{\prime \prime}$ standard inner & & $\mathrm{X} 09 \mathrm{C}$ & 10.91 & 0.95 \\
\hline $17^{\prime \prime}$ standard assembly & MK IV & $\mathrm{B} 09 \times 09 \mathrm{C}$ & 34.10 & \\
\hline $12^{\prime \prime}$ standard outer & & A09D & 13.35 & 0.95 \\
\hline $12^{n}$ standard inner & & NOSD & 6.65 & 0.95 \\
\hline $12^{*}$ standard assembly & MK IC & A09N09D & 20.00 & \\
\hline $26^{\prime \prime}$ natural outer & & BO7E & 35.10 & 0.71 \\
\hline $26^{\prime \prime}$ natural inner & & NO7E & 16.50 & 0.71 \\
\hline 26" natural assembly & MK IVB & B07N07E & 51.60 & \\
\hline 23 " natural outer & & $\mathrm{B} 07 \mathrm{~A}$ & 31.12 & 0.71 \\
\hline 23 " natural inner & & N07A & 14.64 & 0.71 \\
\hline 23 " natural assembly & MK IVB & B07N07A & 45.76 & \\
\hline $20 "$ natural outer & & A07B & 24.01 & 0.71 \\
\hline 20 natural inner & & N07B & 11.99 & 0.71 \\
\hline 20" natural assembly & MK IB & A07N07B & 36.00 & \\
\hline $21^{\prime \prime}$ special outer & & $\mathrm{B} 15 \mathrm{M}$ & 28.11 & 1.15 \\
\hline $21 "$ special inner & & $\mathrm{X09M}$ & 13.10 & 0.95 \\
\hline $21 "$ special assembly & MK IVC & $\mathrm{B} 15 \mathrm{X09 \textrm {M }}$ & 41.21 & 1.085 average \\
\hline \multicolumn{5}{|c|}{ Enrichment Tester Standards ${ }^{2}$} \\
\hline 6" outer & & & & 0.71 \\
\hline $6 "$ outer & & & & 0.95 \\
\hline $6^{n}$ outer & & & & 1.25 \\
\hline \multicolumn{5}{|c|}{ Possibly in the Basin $(s)^{3}$} \\
\hline $17^{\prime \prime}$ natural outer & & $\mathrm{B} 07 \mathrm{C}$ & 23.19 & 0.71 \\
\hline $17^{\prime \prime}$ natural inner & & $\mathrm{X} 07 \mathrm{C}$ & 10.91 & 0.71 \\
\hline 17 " natural assembly & & $\mathrm{B} 07 \times 07 \mathrm{C}$ & 34.10 & \\
\hline
\end{tabular}




\begin{tabular}{||l|l|r|r||}
\hline \multicolumn{4}{|c|}{ English Dimensions for N Reactor Fuel (Bergsman 1994) } \\
\hline \hline Mark Letter & Piece & o.d. (inches) & i.d. (inches) \\
\hline A & Outer & 2.40 & 1.77 \\
\hline B & Outer & 2.42 & 1.70 \\
\hline N & Inner & 1.25 & 0.44 \\
\hline X & Inner & 1.28 & 0.48 \\
\hline
\end{tabular}

\begin{tabular}{|l|c|c|c|c||}
\hline \multicolumn{5}{|c|}{ English Dimensions for K Basins SPR Fuel (Doriss, 1968) } \\
\hline \hline Model & Factor Weight, lbs. & Length, inches & Enrichment, wt\% 235 U & Piece Count \\
\hline K5AD & 8.52 & 8.0 & 0.14 & 532 \\
\hline K5D & 7.86 & 8.0 & 0.14 & 245 \\
\hline K1D & 6.74 & 7.0 & 0.22 & 2 \\
\hline W1D & $7.86^{4}$ & 8.0 & 0.0673 & 786 \\
\hline C2N & 7.36 & 8.0 & 0.71 & 2 \\
\hline K5N & 7.86 & 8.0 & 0.71 & 42 \\
\hline K4N & 7.28 & 8.0 & 0.71 & 3 \\
\hline K4W & 5.21 & 6.0 & 0.71 & 1 \\
\hline O3N & 7.42 & 8.0 & 0.71 & 15 \\
\hline C3E & 5.29 & 6.0 & 0.95 & 42 \\
\hline K5E & 5.50 & 6.0 & 0.95 & 29 \\
\hline O3E & 5.36 & 6.0 & 0.95 & 47 \\
\hline K5A & $4.60^{5}$ & & & \\
\hline
\end{tabular}




\begin{tabular}{|c|c|c|c|c|}
\hline \multicolumn{5}{|c|}{ Metric Factor Weights for N Reactor Fuel in K Basins } \\
\hline Description & Fuel Type & Fuel Code & Factor Weight, kg & Enrichment wt \% ${ }^{235} \mathrm{U}$ \\
\hline $66 \mathrm{~cm}$ spike outer & & A12E & 13.92 & 1.25 \\
\hline $66 \mathrm{~cm}$ spike inner & & NO9E & 6.95 & 0.95 \\
\hline $66 \mathrm{~cm}$ spike assembly & MK IA & A12NO9E & 20.87 & \\
\hline $53 \mathrm{~cm}$ spike. outer & & $\mathrm{A} 12 \mathrm{M}$ & 11.14 & 1.25 \\
\hline $53 \mathrm{~cm}$ spike inner & & NO9M & 5.52 & 0.95 \\
\hline $53 \mathrm{~cm}$ spike assembly & MK LA & A12N09M & 16.66 & \\
\hline $49.5 \mathrm{~cm}$ spike outer & & A12T & 10.43 & 1.25 \\
\hline $49.5 \mathrm{~cm}$ spike inner & & $\mathrm{NOST}$ & 5.16 & 0.95 \\
\hline $49.5 \mathrm{~cm}$ spike assembly & MK IA & A12NO9T & 15.59 & \\
\hline $38 \mathrm{~cm}$ spike outer & & $\mathrm{A} 12 \mathrm{~F}$ & 7.89 & 1.25 \\
\hline $38 \mathrm{~cm}$ spike inner & & No9F & 3.90 & 0.95 \\
\hline $38 \mathrm{~cm}$ spike assembly & MK IA & A12FN09F & 11.79 & \\
\hline $66 \mathrm{~cm}$ standard outer & & $\mathrm{B} 09 \mathrm{E}$ & 15.92 & 0.95 \\
\hline $66 \mathrm{~cm}$ standard inner & & X09E & 7.48 & 0.95 \\
\hline $66 \mathrm{~cm}$ standard assembly & MK IV & $\mathrm{B} 09 \times 09 \mathrm{E}$ & 23.40 & \\
\hline $62 \mathrm{~cm}$ standard outer & & B09S & 14.96 & 0.95 \\
\hline $62 \mathrm{~cm}$ standard inner & & X09S & 7.04 & 0.95 \\
\hline $62 \mathrm{~cm}$ standard assembly & MK IV & B09X09S & 22.00 & \\
\hline $58 \mathrm{~cm}$ standard outer & & $\mathrm{B} 09 \mathrm{~A}$ & 14.12 & 0.95 \\
\hline $58 \mathrm{~cm}$ standard inner & & X09A & 6.64 & 0.95 \\
\hline $58 \mathrm{~cm}$ standard assembly & MK IV & B09X09A & 20.76 & \\
\hline $58 \mathrm{~cm}$ standard outer & & $\mathrm{A} 09 \mathrm{~A}$ & 12.68 & 0.95 \\
\hline $58 \mathrm{~cm}$ standard inner & & N09A & 6.33 & 0.95 \\
\hline $58 \mathrm{~cm}$ standard assembly & MK IC & A09N09A & 19.01 & \\
\hline $56 \mathrm{~cm}$ standard outer & & B09R & 13.36 & 0.95 \\
\hline $56 \mathrm{~cm}$ standard inner & & X09R & 6.30 & 0.95 \\
\hline $56 \mathrm{~cm}$ standard assembly & MK IV & B09X09R & 19.66 & \\
\hline $48 \mathrm{~cm}$ standard outer & & A09P & 10.06 & 0.95 \\
\hline $48 \mathrm{~cm}$ standard inner & & N09P & 5.02 & 0.95 \\
\hline $48 \mathrm{~cm}$ standard assembly & MK IC & A09N09P & 15.08 & \\
\hline
\end{tabular}




\begin{tabular}{|c|c|c|c|c|}
\hline \multicolumn{5}{|c|}{ Metric Factor Weights for N Reactor Fuel in $\mathrm{K}$ Basins } \\
\hline Fuel Description & Fuel Type & Fuel Code & Factor weight, kg & Enrichment, wt \% ${ }^{235} \mathrm{U}$ \\
\hline $43 \mathrm{~cm}$ standard outer & & $\mathrm{A} 09 \mathrm{C}$ & 9.20 & 0.95 \\
\hline $43 \mathrm{~cm}$ standard inner & & N09C & 4.59 & 0.95 \\
\hline $43 \mathrm{~cm}$ standard assembly & MK IC & A09N09C & 13.79 & \\
\hline $43 \mathrm{~cm}$ standard outer & & $\mathrm{B} 09 \mathrm{C}$ & 10.59 & 0.95 \\
\hline $43 \mathrm{~cm}$ standard inner & & $\mathrm{X} 09 \mathrm{C}$ & 4.95 & 0.95 \\
\hline $43 \mathrm{~cm}$ standard assembly & MK IV & $\mathrm{B} 09 \times 09 \mathrm{C}$ & 15.47 & \\
\hline $30.5 \mathrm{~cm}$ standard outer & & A09D & 6.06 & 0.95 \\
\hline $30.5 \mathrm{~cm}$ standard inner & & N09D & 3.02 & 0.95 \\
\hline $30.5 \mathrm{~cm}$ standard assembly & MK IC & A09N09D & 9.08 & \\
\hline $66 \mathrm{~cm}$ natural outer & & $\mathrm{B} 07 \mathrm{E}$ & 15.92 & 0.71 \\
\hline $66 \mathrm{~cm}$ natural inner & & N07E & 7.48 & 0.71 \\
\hline $66 \mathrm{~cm}$ natural assembly & MK IVB & B07N07E & 23.41 & . \\
\hline $58 \mathrm{~cm}$ natural outer & & $\mathrm{B} 07 \mathrm{~A}$ & 14.12 & 0.71 \\
\hline $23 "$ natural inner & & N07A & 6.64 & 0.71 \\
\hline $23^{\prime \prime}$ natural assembly & MK IVB & B07N07A & 20.76 & \\
\hline $51 \mathrm{~cm}$ natural outer & & $\mathrm{A} 07 \mathrm{~B}$ & 10.89 & 0.71 \\
\hline $51 \mathrm{~cm}$ natural inner & & No7B & 5.44 & 0.71 \\
\hline $51 \mathrm{~cm}$ natural assembly & MK IB & $\mathrm{A} 07 \mathrm{~N} 07 \mathrm{~B}$ & 16.33 & \\
\hline $53 \mathrm{~cm}$ special outer & & $\mathrm{B} 15 \mathrm{M}$ & 12.75 & 1.15 \\
\hline $53 \mathrm{~cm}$ special inner & & $\mathrm{X} 09 \mathrm{M}$ & 5.94 & 0.95 \\
\hline $53 \mathrm{~cm}$ special assembly & MK IVC & $\mathrm{B} 15 \mathrm{X} 09 \mathrm{M}$ & 18.69 & 1.085 average \\
\hline \multicolumn{5}{|c|}{ Enrichment Tester Standards } \\
\hline $15 \mathrm{~cm}$ outer & & & & 0.71 \\
\hline $15 \mathrm{~cm}$ outer & & & & 0.95 \\
\hline $15 \mathrm{~cm}$ outer & & & & 1.25 \\
\hline \multicolumn{5}{|c|}{ Possibly in the Basin(s) } \\
\hline $43 \mathrm{~cm}$ natural outer & & $\mathrm{B} 07 \mathrm{C}$ & 10.52 & 0.71 \\
\hline $43 \mathrm{~cm}$ natural inner & & $\mathrm{X} 07 \mathrm{C}$ & 4.95 & 0.71 \\
\hline $43 \mathrm{~cm}$ natural assembly & & $\mathrm{B} 07 \times 07 \mathrm{C}$ & 15.47 & \\
\hline
\end{tabular}




\begin{tabular}{|c|c|c|c|}
\hline \multicolumn{4}{|c|}{ Metric Dimensions For N Reactor Fuel } \\
\hline Mark Letter & Piece & o.d. $(\mathrm{cm})$ & i.d. (cm) \\
\hline A & Outer & 6.10 & 4.50 \\
\hline B & Outer & 6.15 & 4.32 \\
\hline $\mathrm{N}$ & Inner & 3.18 & 1.12 \\
\hline $\mathbf{x}$ & Inner & 3.25 & 1.22 \\
\hline
\end{tabular}

\begin{tabular}{||l|c|c|c|c||}
\hline \multicolumn{5}{|c|}{ Metric Dimensions for K Basins SPR Fuel } \\
\hline \hline Model & Factor Weight, kg & Length, cm & Enrichment, wt\% ${ }^{235}$ U & Piece Count \\
\hline \hline K5AD & 3.86 & 20.3 & 0.14 & 532 \\
\hline K5D & 3.57 & 20.3 & 0.14 & 245 \\
\hline K1D & 3.06 & 17.8 & 0.22 & 2 \\
\hline W1D & 3.57 & 20.3 & 0.0673 & 786 \\
\hline C2N & 3.34 & 20.3 & 0.71 & 2 \\
\hline K5N & 3.58 & 20.3 & 0.71 & 42 \\
\hline K4N & 3.30 & 20.3 & 0.71 & 3 \\
\hline K4W & 2.36 & 15.2 & 0.71 & 1 \\
\hline O3N & 3.37 & 20.3 & 0.71 & 15 \\
\hline C3E & 2.40 & 15.2 & 0.95 & 42 \\
\hline K5E & 2.49 & 15.2 & 0.95 & 29 \\
\hline O3E & 2.43 & 15.2 & 0.95 & 4 \\
\hline K5A & 2.09 & 12.7 & 1.25 & 47 \\
\hline
\end{tabular}


WHC-SD-SNF-CSER-003 Rev 0

References:

Bergsman, K.H., 1994, WHC-SD-SNF-TI-001 Rev 0, Hanford spent Fuel Inventory Baseline, Westinghouse Hanford Co., Richland, WA.

Doriss, C.P., 1968, DUN Conventional Reactors Fuel Element Factor Weights, memo of March 14, 1968.

Doriss, C.P., 1970, DUN-6926, Factor Weights for NPR Fuel Elements, Douglas United Nuclear Inc., Richland, WA.

Locati, V.K., 1986, UNI-278 Rev 12, Factor Weights for $N$ Fuel Elements Effective October 1, 1986, UNC Nuclear Industries, Richland, WA. 
WHC-SD-SNF-CSER-003 Rev 0

\section{Notes}

1. The source for the listing of fuel currently stored in the $\mathrm{K}$ Basins is from the $5 / 1 / 89$ issue date of Process standard $\mathrm{C}$ 300 (WHC-NR-M-2 Vol. 3 ).

2. Enrichment standards were used during the fuel segregation project at $K$ East (circa 1983) and were not a fuel type for reactor use.

3. The factor weight for this fuel model is given in UNI-278 Rev12 but is not listed in the 1989 Process standard $\mathrm{C}-300$.

4. Safeguards and Security has assigned the WID designation for this fuel. The actual depleted uranium SPR fuel models were $\mathrm{K} 1 \mathrm{D}, \mathrm{K} 2 \mathrm{D}, \mathrm{K} 4 \mathrm{D}, \mathrm{K} 5 \mathrm{D}, \mathrm{K} 5 \mathrm{AD}$, and $\mathrm{O} 3 \mathrm{D}$. The factor weight and length assigned by Safeguards is equivalent to the K5D model; the enrichment is the estimated ${ }^{235} \mathrm{U}$ content after irradiation.

5. Dorriss (1968) lists the K5A factor weight as 4.96 Ibs. The Metal Accountability record (MAC) states that a total of 47 pieces are in $K$ West with a total weight of 216.20 lbs. This is an average of $4.60 \mathrm{lbs}$. per piece. 
WHC-SD-SNF-CSER-003 Rev 0

Appendix B

Figures

B1 
Figure 1 K Basin Plan (Typical)

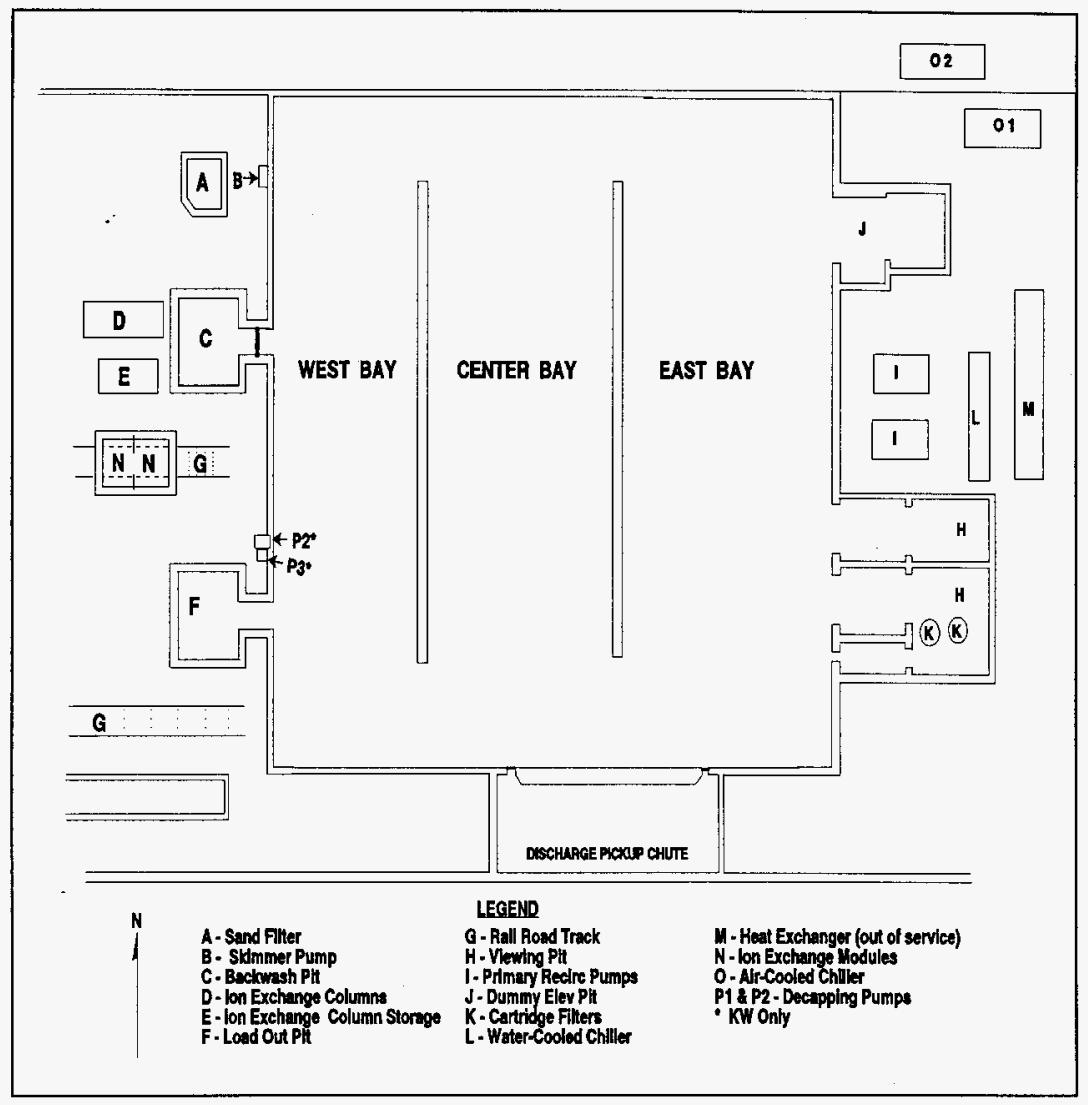




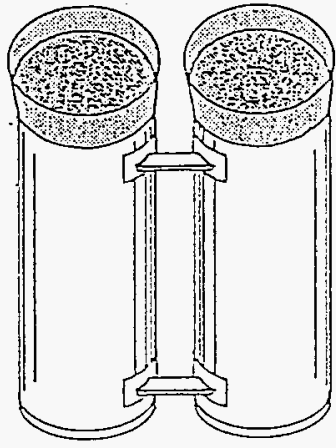

A. Lower Enriched Fuel MKO Canisters

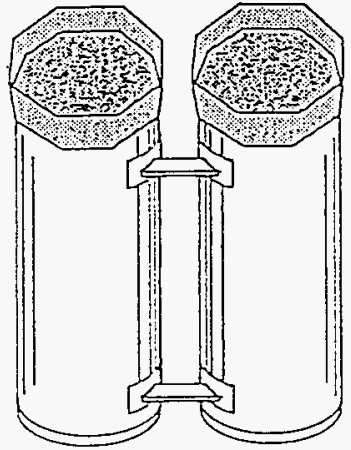

B. Splke Fuel MK O Canisiers
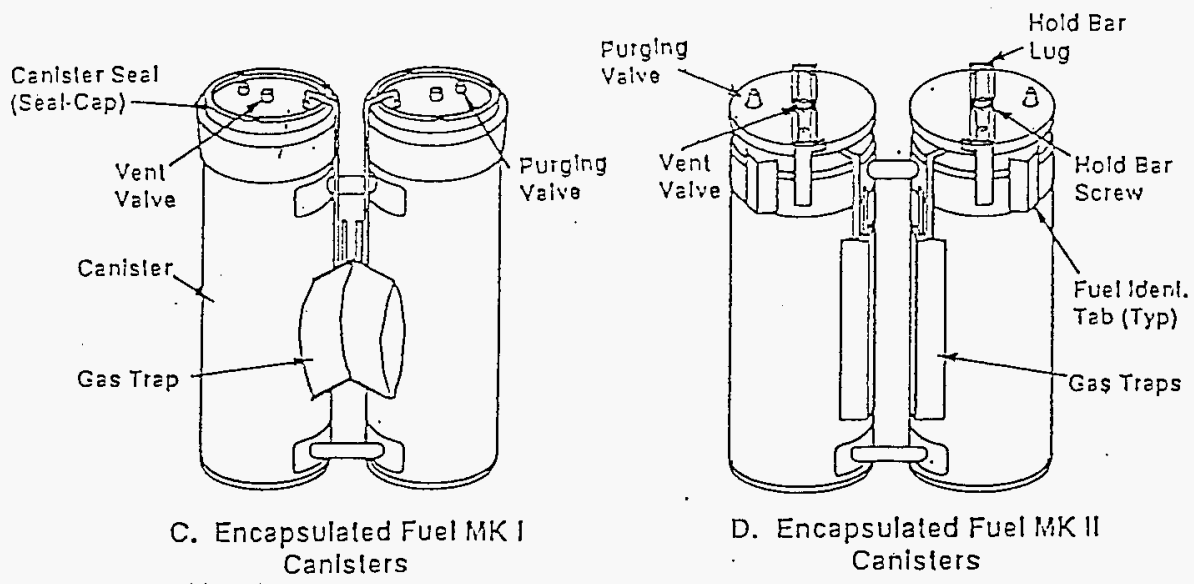
WHC-SD-SJF-CSER-003 REV D

Figure 3 K Basin Fuel storage Racks

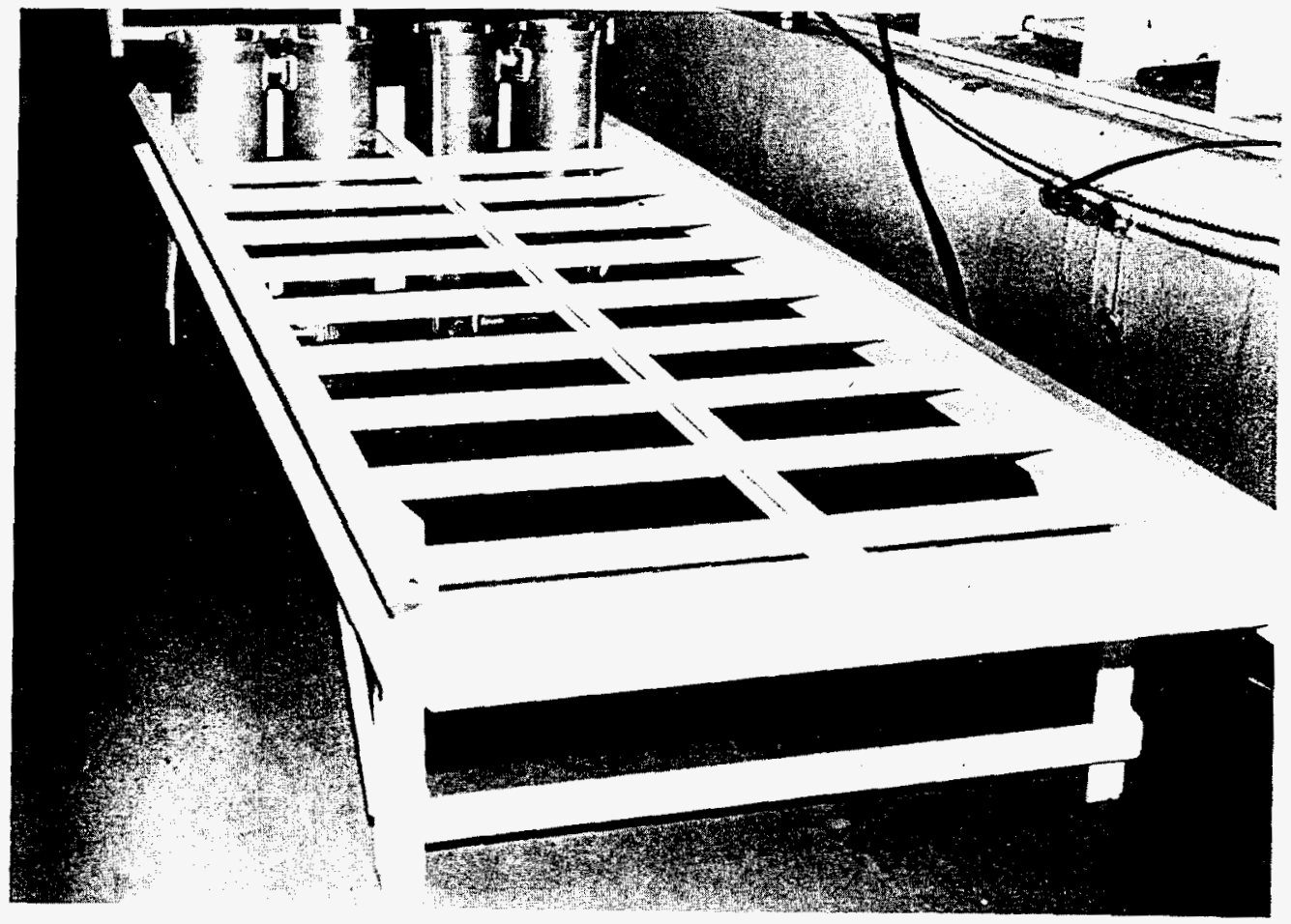




\section{Figure 4 N Reactor Fuel Assembly}

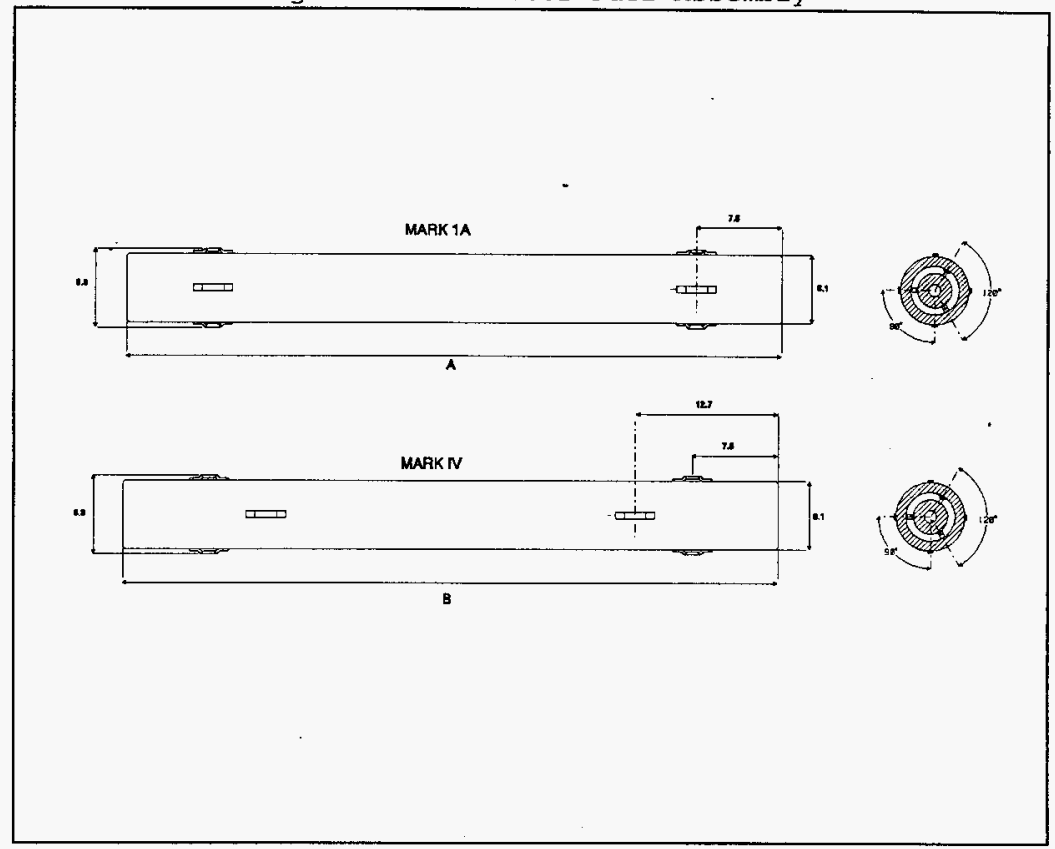


WHC-SD-SNF-CSER-003 Rev 0

Appendix C

Technical Peer Review

C1 
WHC-SD-SNF-CSER-003 Rev 0

\section{Technical Peer Review}

Technical review of this evaluation was provided by A. L. Hess of the Criticality Evaluation Team of the Nuclear Physics and

Shielding section of Safety Analyses and Nuclear Engineering, who provides the following comments.

This report is found to be an accurate and concise summary of the evaluations reported in the past to support the criticality safety limits governing fuel storage in the $\mathrm{K}$-basins, and of the defining calculated criticality parameters. Studies by this reviewer of the referenced evaluation reports, as part of technical reviews on other Criticality Safety Evaluation Reports (CSERs) pertaining to $\mathrm{N}$-fuel element storage, have confirmed the adequacy of the safety margins for unburned fuel, and indicated the extra conservatism inherent to assuming green fuel in the $K$ basins.

Comments submitted from reviews of earlier drafts of this document, including requests for further details of the stored fuel and the facilities, have been well accommodated in this final version. 


\section{DISTRIBUTION SHEET}

\begin{tabular}{|c|c|c|c|c|c|}
\hline \multirow{2}{*}{$\begin{array}{l}\text { To } \\
\text { Distribution }\end{array}$} & \multirow{2}{*}{\multicolumn{3}{|c|}{$\begin{array}{l}\text { From } \\
\text { Standards and Requirements }\end{array}$}} & \multicolumn{2}{|l|}{ Page 1 of 1} \\
\hline & & & & \multicolumn{2}{|c|}{ Date April 17, 1996} \\
\hline \multicolumn{4}{|c|}{ Project Title/Work Order } & \multicolumn{2}{|c|}{ EDT No. 613723} \\
\hline \multicolumn{4}{|c|}{$\begin{array}{l}\text { WHC-SD-SNF-CSER-003, "K Basins Consolidtated Fuel Storage and } \\
\text { Handling Criticality Safety Evaluation" }\end{array}$} & \multicolumn{2}{|c|}{ ECN No. N/A } \\
\hline Name & MSIN & $\begin{array}{l}\text { Text } \\
\text { With All } \\
\text { Attach. }\end{array}$ & Text Only & $\begin{array}{l}\text { Attach./ } \\
\text { Appendix } \\
\text { Only }\end{array}$ & $\begin{array}{l}\text { EDT/ECN } \\
\text { Only }\end{array}$ \\
\hline C. L. Bennett & $\times 3-79$ & $\mathrm{x}$ & & & \\
\hline D. G. Erickson : & HO-38 & $x$ & & & \\
\hline J. Greenborg & $\mathrm{H} 0-35$ & $\mathrm{x}$ & & & \\
\hline A. L. Hess & H0-35 & $\mathrm{x}$ & & & \\
\hline D. 0 . Hess & $x 3-80$ & $x$ & & & \\
\hline M. A. Jensen & $\times 3-79$ & $x$ & & & \\
\hline E. M. Miller & HO-35 & $x$ & & & \\
\hline J. A. Reddick & B1-44 & $x$ & & & \\
\hline K. N. Schwinkendorf & HO-38 & $x$ & & & \\
\hline Central Files (2) & $A 3-88$ & $x$ & & & \\
\hline
\end{tabular}

